\title{
PENGARUH STRATEGI PEMBELAJARAN GENIUS LEARNING TERHADAP HASIL BELAJAR FISIKA SISWA
}

\author{
Henok Siagian dan Irwan Susanto \\ Jurusan Fisika, FMIPA Universitas Negeri Medan \\ Jl. Willem Iskandar, Psr V-Medan
}

\begin{abstract}
Abstrak. Penelitian ini bertujuan untuk mengetahui peningkatan hasil belajar Fisika siswa dengan menerapkan strategi pembelajaran Genius Learning. Subjek penelitian adalah siswa kelas X SMA Negeri 1 Pancur Batu, di mana dari kelas X-A sebagai kelas eksperimen (strategi pembelajaran Genius Learning) dan kelas X-B sebagai kela kontrol (pembelajaran konvensional) dengan masing-masing kelas berjumlah 40 siswa. Penelitian ini merupakan jenis penelitian quasi experiment dengan menggunakan metode groups pretest-posttest desaign dalam pengambilan data penelitian. Berdasarkan data yang diperoleh dari hasil penelitian menunjukkan, bahwa rata-rata hasil belajar fisika siswa dengan strategi pembelajaran Genius Learning mengalami peningkatan. Data penelitian berupa hasil belajar kognitif diperoleh dari test hasil belajar yang diperoleh untuk mengetahui peningkatan hasil belajar siswa. Hasil analisis data menunjukkan adanya peningkatan hasil belajar kognitif. Dari hasil analisis tersebut dapat disimpulkan bahwa penerapan stategi pembelajaran Genius Learning dapat meningkatkan hasil belajar fisika siswa.
\end{abstract}

Keywords: genius Learning, cognitive ability, hasil belajar

\section{PENDAHULUAN}

Pendidikan IPA-Fisika merupakan pelajaran eksakta yang mempelajari tentang pengetahuan yang rasional dan objektif mengenai alam semesta beserta segala isinya. IPAFisika ialah suatu kumpulan pengetahuan yang tersusun secara sistematik, yang di dalam penggunaannya secara umum terbatas pada gejala-gejala alam. Hakekat IPA-Fisika seharusnya tercermin dalam tujuan pendidikan IPAFisika dan strategi mengajar yang digunakan. IPA memperoleh kebenaran secara empirik. Kunci pendekatan empirik berdasarkan atas pengamatan yang dilakukan. IPA merupakan suatu bentuk upaya menjadikan berbagai pengalaman menjadi suatu sistem pola berpikir yang logis. Sains merupakan karya manusia yang dihasilkan atau ditemukan lewat metode ilmiah dan keterampilan proses sains.

IPA mempelajari gejala alam melalui proses dan sikap ilmiah tertentu. Proses itu misalnya pengamatan dan eksperimen dengan sikap ilmiah yang objektif, jujur, terbuka pada saat pengumpulan data-data. Proses yang bersikap ilmiah, sains memperoleh penemuanpenemuan berupa fakta maupun teori yang mendasar sampai pada tahap modern. Penemuan yang berupa fakta dan teori ini disebut produk IPA. Secara garis besar IPA dapat didefinisikan sebagai sikap ilmiah, proses ilmiah dan produk ilmiah yang disebut sebagai hakekat IPA. Dari pengertian di atas, hakekat belajar Fisika adalah upaya untuk mengubah perilaku menjadi seorang pemecah masalah dan mencari temuan ilmiah yang dilandasi oleh sikap-sikap ilmiah.

Fisika merupakan salah satu bidang yang menduduki peranan penting dalam pendidikan yang cukup menarik dipelajari. Namun, pada kenyataanya banyak siswa yang menganggap bahwa pelajaran Fisika merupakan mata pelajaran yang membutuhkan waktu, pemikiran 
dan keinginan belajar yang lebih dibandingkan mata pelajaran yang lain karena materinya mengarah pada perhitungan dan rumus-rumus. Keadaan seperti ini mungkin dikarenakan penyampaian pengajaran Fisika itu sendiri dalam penyajiannya selalu berupa ceramah, sehingga pembelajaran Fisika kurang menarik, monoton ataupun kosep-kosep yang dipakai tidak sederhana sehingga tidak mudah untuk dipahami oleh siswa.

Menggunakan metode ceramah dalam pembelajaran sains, mengakibatkan pembelajaran sains yang kurang efektif karena siswa hanya mendengarkan penjelasan guru dan mencatat hal-hal penting. Selain itu, guru hanya menganggap bahwa mengajar bukan sebagi suatu hal yang dianggap sebagai tanggung jawab yang tulus. Gunawan (2007) mengatakan bahwa dalam mengajar guru masih berpandangan kuno dan berpikiran bahwa tugas seorang guru hanyalah menyampaikan materi sedangkan tugas siswa itu sendiri hanya mengerti apa yang disampaikan oleh guru.

Situasi seperti ini sedikit banyaknya dapat mempengaruhi minat siswa untuk dapat terpancing dalam belajar, sehingga motivasi serta ekspektasi siswa untuk mempelajari lebih dalam tentang pelajaran Fisika itu sendiri akan memiliki pengaruh terhadap minat belajar siswa. Dengan motivasi serta ekspektasi yang rendah, hal ini tentu akan mempengaruhi prestasi hasil belajar Fisika siswa. Gunawan (2007) mengatakan, tingkat ekspektasi yang kita berikan kepada siswa akan memiliki nilai yang berbanding lurus dengan prestasi hasil belajar, jika tingkat ekspektasi siswa tinggi terhadap pelajaran maka akan seiring dengan peningkatan prestasi dan sebaliknya. Untuk itu diperlukan suatu strategi pembelajaran dengan rangkaian pendekatan praktis dalam pembelajaran dengan strategi Genius Learning. Gunawan (2007) mengatakan, tujuan pembelajaran dengan strategi pembelajaran Genius Learning pada intinya adalah bagaimana membuat proses pembelajaran menjadi efektif, efisien, dan menyenangkan.
Strategi pembelajaran Genius Learning dalam penerapan dan hasilnya diharapkan dapat membantu siswa untuk bisa mengerti kekuatan serta kelebihan potensi yang mereka miliki yang dapat dikembangkan. Dalam penerapan strategi pembelajaran Genius Learning siswa diposisikan sebagai pusat dari proses pembelajaran atau subjek pendidikan, tidak seperti yang selama ini di mana siswa diposisikan sebagai objek pendidikan. Dengan penerapan strategi pembelajaran Genius Learning dalam proses belajar, siswa diharapkan tidak hanya mendengar konsep-konsep Fisika saja, melainkan juga dapat memahami, melihat, mempraktekkan dan mendemonstrasikan secara langsung bagaimana proses konsep-konsep itu terjadi dengan nyata dalam pembelajaran. Adapun sintaks penerapan strategi pembelajaran Genius Learning dengan efektif dan efisien secara step by step seperti yang tertera dalam Tabel 1.

Tabel 1. Sintaks Strategi Pembelajaran Genius Learning

\begin{tabular}{|l|l|}
\hline \multicolumn{1}{|c|}{ Fase-Fase } & \multicolumn{1}{|c|}{ Peranan Guru } \\
\hline $\begin{array}{l}\text { Fase 1 } \\
\text { Konasana }\end{array}$ & $\begin{array}{l}\text { Guru berusaha memenuhi kebu- } \\
\text { tuhan akan rasa aman, dicintai } \\
\text { dan dihargai pada awal pertemuan } \\
\text { sebelum memulai proses belajar. }\end{array}$ \\
\hline $\begin{array}{l}\text { Fase 2 } \\
\text { Hubungkan }\end{array}$ & $\begin{array}{l}\text { Guru berusaha memberikan } \\
\text { afirmasi positif tentang materi } \\
\text { yang akan dipelajari, sehingga } \\
\text { membantu siswa dalam menghu- } \\
\text { bungkan apa yang diketahui oleh } \\
\text { siswa dengan materi ajar serta } \\
\text { apa yang mungkin dimanfaatkan } \\
\text { oleh siswa itu sendiri dari } \\
\text { informasi yang diketahui dengan } \\
\text { arahan guru. }\end{array}$ \\
\hline $\begin{array}{l}\text { Fase 3 } \\
\text { Gambaran } \\
\text { Besar }\end{array}$ & $\begin{array}{l}\text { Guru memberi ringkasan dasar } \\
\text { tentang materi yang akan dipela- } \\
\text { jari sebagai pemacu memori } \\
\text { ingatan siswa. }\end{array}$ \\
\hline $\begin{array}{l}\text { Fase 4 } \\
\text { Tujuan }\end{array}$ & $\begin{array}{l}\text { Guru menyampaikan tujuan yang } \\
\text { akan dicapai dari proses akhir. }\end{array}$ \\
\hline
\end{tabular}




\begin{tabular}{|l|l|}
\hline $\begin{array}{l}\text { Fase 5 } \\
\text { Pemasukan }\end{array}$ & $\begin{array}{l}\text { Guru melibatkan beberapa gaya } \\
\text { mengajar sehingga proses } \\
\text { penyampaian informasi memiliki } \\
\text { keunikan tersendiri serta menarik } \\
\text { dengan konsep-konsep Fisika } \\
\text { yang sederhana tetapi mudah } \\
\text { dipahami oleh siswa. }\end{array}$ \\
\hline $\begin{array}{l}\text { Fase 6 } \\
\text { Aktivasi }\end{array}$ & $\begin{array}{l}\text { Guru memberikan tindakan } \\
\text { positif kepada siswa untuk } \\
\text { mengetahui sejauh mana tingkat } \\
\text { pemahaman siswa terhadap }\end{array}$ \\
\hline $\begin{array}{l}\text { Fase 7 } \\
\text { Demonstrasi }\end{array}$ & $\begin{array}{l}\text { Guru memberikan ujian pada } \\
\text { saat itu juga tentang seputar } \\
\text { pengetahuan, pemahaman serta } \\
\text { saat yang tepat memberikan } \\
\text { umpan balik dari informasi yang } \\
\text { didapat siswa. }\end{array}$ \\
\hline $\begin{array}{l}\text { Fase 8 } \\
\text { Ulangi dan } \\
\text { Jangkarkan }\end{array}$ & $\begin{array}{l}\text { Guru melakukan penjangkaran } \\
\text { dan pengulangan pada setiap } \\
\text { proses dengan suasana yang } \\
\text { menyenangkan dan nyaman dan } \\
\text { memberikan kesimpulan akhir }\end{array}$ \\
\hline
\end{tabular}

Tujuan penelitian ini adalah untuk: (1) mengetahui kecenderungan hasil belajar Fisika dengan menggunakan strategi pembelajaran Genius Learning. (2) Mengetahui kecenderungan hasil belajar Fisika menggunakan pembelajaran Konvensional. (3) Mengetahui pengaruh yang signifikan terhadap penggunaan strategi pembelajaran Genius Learning.

\section{METODE PENELITIAN}

Penelitian ini merupakan penelitian quasi eksperimen. Populasi dalam penelitian ini adalah seluruh siswa SMA Negeri 1 Pancur Batu kelas $\mathrm{X}$ yang terdiri atas 7 kelas paralel dengan jumlah siswa sebanyak 40 orang untuk masing-masing kelas. Sampel penelitian ini ditentukan dengan memilih 2 kelas secara acak (cluster random sampling). Adapun kelas yang dijadikan sebagai sampel penelitian adalah kelas X-A (kelas eksperimen) yang diajar dengan strategi pembelajaran Genius Learning dan kelas X-B (kelas kontrol) yang diajar dengan pembelajaran Konvensional.

Adapun prosedur penelitiannya adalah: (1) Tahapan Persiapan meliputi: (a) Menyusun jadwal penelitian. (b) Membuat program rencana pengajaran. (c) Mempersiapkan butir tes. (2) Tahapan Pelaksanaan meliputi: (a) Menentukan kelas sampel dari kelas yang sudah ada. (b) Melaksanakan pretes pada kelas eksperimen dan kelas kontrol untuk mendapatkan data awal. (c) Melakukan analisis terhadap data pretes yaitu uji normalitas, uji homogenitas dan uji perbedaan nilai rata-rata pretes siswa pada kelas eksperimen dan kelas kontrol. (d) Melakukan pengajaran pada dua kelas yaitu, pada kelas kontrol diberikan perlakuan dengan pembelajaran Konvensional, sedangkan pada kelas eksperimen diberi perlakuan dengan strategi pembelajaran Genius Learning. (e) Memberikan postes pada kelas eksperimen dan kelas kontrol untuk mengetahui hasil belajar siswa setelah diberi perlakuan yang berbeda. (f) Melakukan analisis terhadap data postes yaitu uji normalitas, uji homogenitas, uji t, pada kelas eksperimen dan kelas kontrol, kemudian melakukan uji hipotesis. (3) Setelah uji hipotesis dapat diambil kesimpulan.

Uji Homogenitas.

Untuk uji homogenitas dapat dihitung dengan rumus (Sudjana, 2002):

$$
\mathrm{F}_{\text {Hitung }}=\frac{\text { Varians terbesar }}{\text { Varians terkecil }}
$$

Karena pengujian statistik dalam paneltian ini merupakan uji satu pihak (uji pihak kanan), maka hipotesis nihil $\mathrm{H}_{\mathrm{o}}$ dengan tandingan hipotesis alternatif $\mathrm{H}_{\mathrm{a}}$ adalah:

$\mathrm{H}_{\mathrm{o}} \quad: \sigma_{1}^{2}=\sigma_{2}^{2}$

$\mathrm{H}_{\mathrm{a}}: \sigma_{1}^{2}>\sigma_{2}^{2}$

Adapun kriteria pengujiannya adalah tolak $\mathrm{H}_{\mathrm{O}}$ jika $F_{\text {hitung }} \geq \mathrm{F}_{\text {tabel }}$, jika harga $\mathrm{F}_{\text {hitung }} \leq \mathrm{F}_{\text {tabel }}$ maka hipotesis nihil $\left(\mathrm{H}_{\mathrm{O}}\right)$ diterima. Harga $\mathrm{F}$ tabel diperoleh dengan rumus $F_{(1-\alpha)\left(\mathrm{n}_{1}-1, \mathrm{n}_{2}-1\right)}$ pada taraf kepercayaan $\alpha=0,05$. 


\section{Pengujian Hipotesis Awal}

Sudjana (2002) mengatakan bahwa, jika kedua simpangan baku tidak sama tetapi kedua populasi berdistribusi normal, pendekatan yang cukup memuaskan untuk mengetahui kesamaan rata-rata dua pihak adalah dengan menggunakan statistik $t_{\text {hitung. }}$. Hipotesis yang akan diuji adalah:

Ho $: \overline{\mu_{1}}=\overline{\mu_{2}} \quad$ (kemampuan awal sama)

Ha $: \overline{\mu_{1}}>\overline{\mu_{2}} \quad$ (kemampuan awal tidak sama)

Untuk menguji hipotesis penelitian apakah kebenarannya dapat diterima atau ditolak, dalam penelitian ini penulis menggunakan uji t. Uji t yang digunakan adalah uji satu pihak (uji pihak kanan) dengan membandingkan antara $t_{\text {hitung }}$ dengan $t_{\text {tandingan. }}$ Untuk menghitung

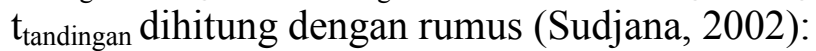

$$
\mathrm{t}_{\text {tandingan }}=\frac{w_{1} t_{1}+w_{2} t_{2}}{w_{1}+w_{2}}
$$

Sedangkan $t_{\text {hitung }}$ dicari dengan rumus (Sudjana, 2002):

$$
\mathrm{t}_{\text {hitung }}=\frac{-\bar{x}_{1}-\bar{x}_{2}}{\sqrt{\mathrm{w}_{1}+w_{2}}}
$$

di mana: $\mathrm{n}_{1}=$ Jumlah sampel yang diajar dengan strategi pembelajaran Genius Learning. $\mathrm{n}_{2}=$ Jumlah sampel yang diajar dengan metode pembelajaran konvensional. $\bar{x}_{1}=$ Rata-rata hasil belajar Fisika pada kelas eksperimen. $\bar{x}_{2}=$ Rata-rata hasil belajar Fisika pada kelas kontrol.

\section{HASIL PENELITIAN DAN PEMBAHASAN}

Hasil Pretes dan Postes Kelas Sampel

Data hasil penelitian terhadap nilai pretes dan nilai postes kelas eksperimen yang diajar dengan strategi pembelajaran Genius Learning dan kelas kontrol yang diuji dengan pembelajaran Konvensional dapat dilihat dalam Tabel 2 dan Tabel 3 dibawah ini.
Tabel 2. Data Nilai Pretes dan Postes

\begin{tabular}{|c|c|c|c|c|c|c|c|}
\hline \multicolumn{4}{|c|}{ Nilai Pretes } & \multicolumn{4}{|c|}{ Nilai Postes } \\
\hline $\begin{array}{l}\mathrm{Ni} \\
\text { lai }\end{array}$ & $\mathrm{F}$ & $\begin{array}{l}\text { Rata- } \\
\text { Rata }\end{array}$ & SD & $\begin{array}{l}\mathrm{Ni} \\
\text { lai }\end{array}$ & $\mathrm{F}$ & $\begin{array}{l}\text { Rata- } \\
\text { Rata }\end{array}$ & SD \\
\hline 10 & 1 & \multirow{11}{*}{36,13} & \multirow{11}{*}{14,12} & 60 & 3 & \multirow{11}{*}{76,63} & \multirow{11}{*}{7,6} \\
\hline 15 & 5 & & & 65 & 2 & & \\
\hline 20 & 3 & & & 70 & 5 & & \\
\hline 25 & 3 & & & 75 & 9 & & \\
\hline 30 & 4 & & & 80 & 13 & & \\
\hline 35 & 3 & & & 85 & 6 & & \\
\hline 40 & 6 & & & 90 & 2 & & \\
\hline 45 & 4 & & & - & - & & \\
\hline 50 & 6 & & & - & - & & \\
\hline 55 & 4 & & & - & - & & \\
\hline 60 & 1 & & & - & - & & \\
\hline$\Sigma$ & 40 & & & $\Sigma$ & 40 & & \\
\hline
\end{tabular}
Kelas Eksperimen.

Tabel 3. Data Nilai Pretes dan Postes

\begin{tabular}{|c|c|c|c|c|c|c|c|}
\hline \multicolumn{4}{|c|}{ Nilai Pretes } & \multicolumn{4}{|c|}{ Nilai Postes } \\
\hline $\begin{array}{c}\text { Nil } \\
\text { ai }\end{array}$ & $\mathrm{F}$ & $\begin{array}{l}\text { Rata- } \\
\text { Rata }\end{array}$ & SD & $\begin{array}{c}\mathrm{Nil} \\
\text { ai }\end{array}$ & $\mathrm{F}$ & $\begin{array}{l}\text { Rata- } \\
\text { Rata }\end{array}$ & SD \\
\hline 15 & 3 & \multirow{10}{*}{37,63} & \multirow{10}{*}{12,76} & 50 & 9 & \multirow{10}{*}{68,50} & \multirow{10}{*}{9,95} \\
\hline 20 & 2 & & & 55 & 4 & & \\
\hline 25 & 4 & & & 60 & 6 & & \\
\hline 30 & 6 & & & 65 & 5 & & \\
\hline 35 & 5 & & & 70 & 4 & & \\
\hline 40 & 6 & & & 75 & 5 & & \\
\hline 45 & 3 & & & 80 & 4 & & \\
\hline 50 & 5 & & & 85 & 3 & & \\
\hline 55 & 4 & & & - & & & \\
\hline 60 & 2 & & & - & & & \\
\hline$\Sigma$ & 40 & & & $\Sigma$ & 40 & & \\
\hline
\end{tabular}
Kelas Kontrol.

Data Uji Normalitas Nilai Pretes dan Postes.

Berdasarkan pengolahan data yang dilakukan, diperoleh hasil uji normalitas seperti yang tertera pada Tabel 4 .

Tabel 4. Data Uji Normalitas.

\begin{tabular}{|l|l|c|c|c|}
\hline \multicolumn{2}{|c|}{ Kelas Sampel } & $\mathrm{L}_{\text {hitung }}$ & $\mathrm{L}_{\text {tabel }}$ & Keterangan \\
\hline \multirow{2}{*}{ Eksperimen } & Pretes & 0,098 & 0,140 & Normal \\
\cline { 2 - 5 } & Postes & 0,130 & 0,140 & Normal \\
\hline \multirow{2}{*}{ Kontrol } & Pretes & 0,101 & 0,140 & Normal \\
\cline { 2 - 5 } & Postes & 0,137 & 0,140 & Normal \\
\hline
\end{tabular}


Uji Homogenitas Kelas Eksperimen dan Kelas Kontrol.

Untuk membuktikan apakah data yang diperoleh berasal dari populasi yang homogen, maka dilakukan uji homogenitas dengan membandingkan harga $F_{\text {hitung }}$ dengan harga $\mathrm{F}_{\text {tabel. }}$. Di mana harga $\mathrm{F}_{\text {tabel }}$ dengan jumlah siswa 40 orang dengan taraf signifikan $\alpha=5 \%$ adalah 1,71 dengan $\mathrm{F}_{\text {hitung }}$ untuk nilai pretes adalah 1,22 dan $\mathrm{F}_{\text {hitumg }}$ untuk nilai postes adalah 1,70. Ternyata $\mathrm{F}_{\text {hitung }} \leq \mathrm{F}_{\text {tabel }}$ hal ini menyatakan bahwa populasi berasal dari varians yang sama (homogen).

\section{Uji Kemampuan Awal}

Uji hipotesis untuk kemampuan awal adalah untuk mengetahui apakah jumlah populasi kedua kelas sampel dalam penelitian memiliki kemampuan yang sama. Sudjana (2002) mengatakan, jika kedua simpangan baku tidak sama tetapi kedua populasi berdistribusi normal, sehingga uji statistik yang digunakan adalah:

$$
\mathrm{t}_{\text {hitung }}=\frac{x_{1}-x_{2}}{\sqrt{\mathrm{w}_{1}+w_{2}}}, .
$$

Adapun kriteria pengujian hitpotesis penelitian. Adapun kriteria pengujian hipotesisnya adalah terima $\mathrm{H}_{\mathrm{O}}$ jika $-\frac{\mathrm{w}_{1} \mathrm{t}_{1}+\mathrm{w}_{2} \mathrm{t}_{2}}{\mathrm{w}_{1}+\mathrm{w}_{2}}<\mathrm{t}_{\text {hitung }}<\frac{\mathrm{w}_{1} \mathrm{t}_{1}+\mathrm{w}_{2} \mathrm{t}_{2}}{\mathrm{w}_{1}+\mathrm{w}_{2}}$ dan tolak $\mathrm{H}_{\mathrm{O}}$ dalam hal lainnya. Dimana $\mathrm{t}_{1}=\mathrm{t}_{(1-1 / 2),\left(\mathrm{n}_{1}-1\right)}$ serta $\mathrm{t}_{2}=\mathrm{t}_{(1-1 / 2),\left(\mathrm{n}_{2}-1\right)}$ dan taraf kepercayaan $\alpha=0,05$. Berdasarkan hasil perhitungan, untuk hipotesis awal diperoleh harga $t_{\text {hitung }}=-0,49$ dengan harga $t_{\text {tandingan }}=2,02$.

Hasil ini menunjukkan bahwa harga $t_{\text {hitung }}$ berada diantara $t_{\text {tandingan }}$ yaitu $-2,02<-0,49<$ 2,02. Ini berarti hipotesis $\mathrm{H}_{\mathrm{O}}$ diterima, tidak ada pengaruh pembelajaran yang signifikan antara nilai pretes kedua kelas.

\section{Pengujian Hipotesis}

Uji hipotesis atau lebih dikenal dengan uji $\mathrm{t}$ adalah uji untuk mengetahui apakah ada pengaruh yang signifikan dengan strategi pembelajaran Genius Learning terhadap hasil belajar Fisika siswa SMA Negeri 1 Pancur Batu pada materi pokok Besaran dan Satuan semester I kelas X T.P. 2010/2011. Untuk mengetahui pengaruh strategi pembelajaran Genius Learning terhadap hasil belajar siswa, maka uji hipotesis yang digunakan adalah uji kesamaan rata-rata satu pihak yaitu uji pihak kanan dengan membandingan harga $t_{\text {hitung }}$ dan harga $t_{\text {tandingan }}$ yang diperoleh dari daftar distribusi $\mathrm{t}$ dengan peluang $t=(1-\alpha)$. Jika $\mathrm{t}_{\text {hitung }} \geq \mathrm{t}_{\text {tabel }}$ pada taraf signifikan $\alpha=0,05$ dan derajat kebebasan $(\mathrm{dk})=\left(\mathrm{n}_{1}-1\right)$ dan $\left(\mathrm{n}_{2}-1\right)$, hal ini menunjukkan bahwa ada pengaruh yang signifikan terhadap hasil belajar fisika siswa dengan penerapan strategi pembelajaran Genius Learning seperti yang tertera dalam Tabel 5.

Tabel 5. Data Uji Hipotesis.

\begin{tabular}{|c|c|c|c|}
\hline \multicolumn{2}{|c|}{ Nilai Postes } & \multirow{2}{*}{$t_{\text {hitung }}$} & \multirow{2}{*}{$t_{\text {tandingan }}$} \\
\cline { 1 - 2 } Eksperimen & Kontrol & & \\
\hline 76,63 & 68,50 & 4,10 & 1,69 \\
\hline
\end{tabular}

Berdasarkan hasil penelitian diperoleh bahwa nilai pretes rata-rata untuk kelas eksperimen yang diajar dengan strategi pembelajaran Genius Learning sebesar 36,13 dengan Standar Deviasi sebesar 14,12 sedangkan untuk kelas kontrol yang diajar dengan pembelajaran konvensional adalah 37,63 dengan Standar Deviasi sebesar 12,76. Setelah proses belajar selesai dengan menerapkan strategi Genius Learning diperoleh nilai postes untuk kelas eksperimen yang diajar dengan strategi pembelajaran Genius Learning sebesar 76,63 dengan Standard Deviasi sebesar 7,63 dan kelas kontrol $\left(\mathrm{X}_{5}\right)$ sebesar 68,50 dengan Standard Deviasi sebesar 98,98. Hasil ini menunjukkan bahwa penerapan strategi pembelajaran Genius Learning memiliki pengaruh yang signifikan terhadap hasil pembelajaran.

Hasil perhitungan uji normalitas, uji homogenitas dan perhitungan kemampuan awal siswa. Untuk uji normalitas diperoleh $\mathrm{L}_{\mathrm{hitung}}$ nilai pretes kelas eksperimen adalah 0,098 dan $\mathrm{L}_{\text {hitung }}$ nilai postes kelas eksperimen (X-A) adalah $0,130, \mathrm{~L}_{\text {hitung }}$ nilai pretes kelas kontrol 
(X-B) adalah $0,101, \mathrm{~L}_{\text {hitung nilai postes kelas }}$ kontrol adalah 0,137 , di mana harga $\mathrm{L}_{\text {tabel }}$ dengan jumlah siswa 40 orang diperoleh sebesar 0,140. Sesuai dengan kriteria pengujian hipotesis, jika $\mathrm{L}_{\text {hitung }}<\mathrm{L}_{\text {tabel }}$ maka sampel berasal dari populasi yang berdistribusi normal.

Sedangkan untuk mengetahui bahwa populasi dari sampel yang memiliki kemampuan yang sama dilakukan uji homogenitas dengan membandingkan harga $\mathrm{F}_{\text {hitung }}$ dengan $F_{\text {tabel. }}$. Dengan kriteria pengujian untuk uji pihak kanan adalah tolak $\mathrm{H}_{\mathrm{O}}$ jika $\mathrm{F}_{\text {hitung }} \geq \mathrm{F}_{\text {tabel }}$, jika harga $\mathrm{F}_{\text {hitung }} \leq \mathrm{F}_{\text {tabel }}$ maka hipotesis nihil $\left(\mathrm{H}_{\mathrm{O}}\right)$ diterima. Harga $F_{\text {tabel }}$ diperoleh dengan rumus $\mathrm{F}_{(1-\alpha)\left(\mathrm{n}_{1}-1, \mathrm{n}_{2}-1\right)}$. Dimana $\mathrm{H}_{\mathrm{O}}$ menyatakan bahwa populasi memiliki varians yang homogen. Berdasarkan nilai pretes kelas eksperimen $\left(\mathrm{X}_{1}\right)$ dan kelas kontrol $\left(\mathrm{X}_{5}\right)$ diperoleh harga $F_{\text {hitung }}$ sebesar 1,22 dan $F_{\text {hitung }}$ nilai postes untuk kelas eksperimen $\left(\mathrm{X}_{1}\right)$ dan kelas kontrol $\left(\mathrm{X}_{5}\right)=1,70$. Jika dibandingkan dengan nilai $\mathrm{F}_{\text {tabel }}$ sebesar 1,71 menunjukkan bahwa data penelitian yang diambil berasal dari siswa dengan kemampuan yang sama karena harga $F_{\text {hitung }}<F_{\text {tabel. }}$. Sedangkan untuk uji kemampuan awal kedua kelas sampel diperoleh harga $\mathrm{t}$ untuk $\mathrm{t}_{\text {tandingan }}=2,02$ dan $\mathrm{t}_{\text {tabel }}=-0,49$. Harga $t$ tersebut menunjukkan bahwa harga $\mathrm{t}_{\text {tandingan }}=2,03>\mathrm{t}_{\text {tabel }}=-0,49$. Hasil ini menunjukkan bahwa Ho diterima bahwa kedua populasi memiliki kemampuan yang sama.

Untuk mengetahui sejauh mana pengaruh strategi pembelajaran Genius Learning dapat diketahui dengan hasil uji t yaitu uji pihak kanan. Dengan kriteria pengujian adalah membandingkan harga $t_{\text {hitung }}$ dengan harga $\mathrm{t}_{\text {tandingan }}$ yang diperoleh dari daftar distribusi $\mathrm{t}$ dengan peluang $t=(1-\alpha)$. Dari perhitungan uji $\mathrm{t}$ diperoleh nilai $t_{\text {hitung }}$ untuk postes kelas eksperimen (X-A) 4,10 dan kelas kontrol (X-B) yang diajar dengan pembelajaran konvensional

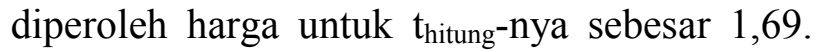

Nilai distribusi $\mathrm{t}$ di atas menunjukkan bahwa harga $\mathrm{t}_{\text {hitung }}>\mathrm{t}_{\text {tandingan }}$ dan menolak $\mathrm{H}_{\mathrm{o}}$ dan menerima $\mathrm{H}_{\mathrm{a}}$.

Harga uji $\mathrm{t}$ menunjukkan bahwa ada pengaruh yang signifikan terhadap hasil belajar Fisika siswa dengan penerapan pembelajaran yang diajar dengan strategi pembelajaran Genius Learning dan pembelajaran Konvensional pada Materi Pokok Besaran dan Satuan Semester I Kelas X di SMA Negeri 1 Pancur Batu Tahun Pelajaran 2010/2011.

\section{Kesimpulan}

Berdasarkan hasil analisis data dapat disimpulkan bahwa adanya peningkatan hasil belajar kognitif siswa dengan menerapkan strategi pembelajaran Genius Learning dibandingkan dengan pembelajaran yang biasanya diberikan oleh guru yaitu pembelajaran yang konvensional pada materi Besaran dan Satuan.

Adapun saran dalam menerapkan strategi pembelajaran Genius Learning berdasarkan pengalaman dan teori tentang penerapan strategi pembelajaran Genius Learning adalah: (1) Penerapan strategi pembelajaran Genius Learning akan lebih maksimal jika kita menguasai prinsip-prinsip atau langkah-langkah dalam penerapan strategi pembelajaran Genius Learning dalam dalam kelas. (2) Kepada guruguru disarankan untuk menggunakan pembelajaran dengan strategi pembelajaran Genius Learning pada mata pelajaran dengan materi pokok yang berbeda.

\section{DAFTAR PUSTAKA}

Gunawan, A.W. 2007. Strategi Genius Learning. Jakarta: Gramedia Pustaka.

Gunawan, A.W. 2007. Born to be a Genius. Jakarta: Gramedia Pustaka.

Sudjana. 2002. Metode Statistik. Bandung: Tarsito. 